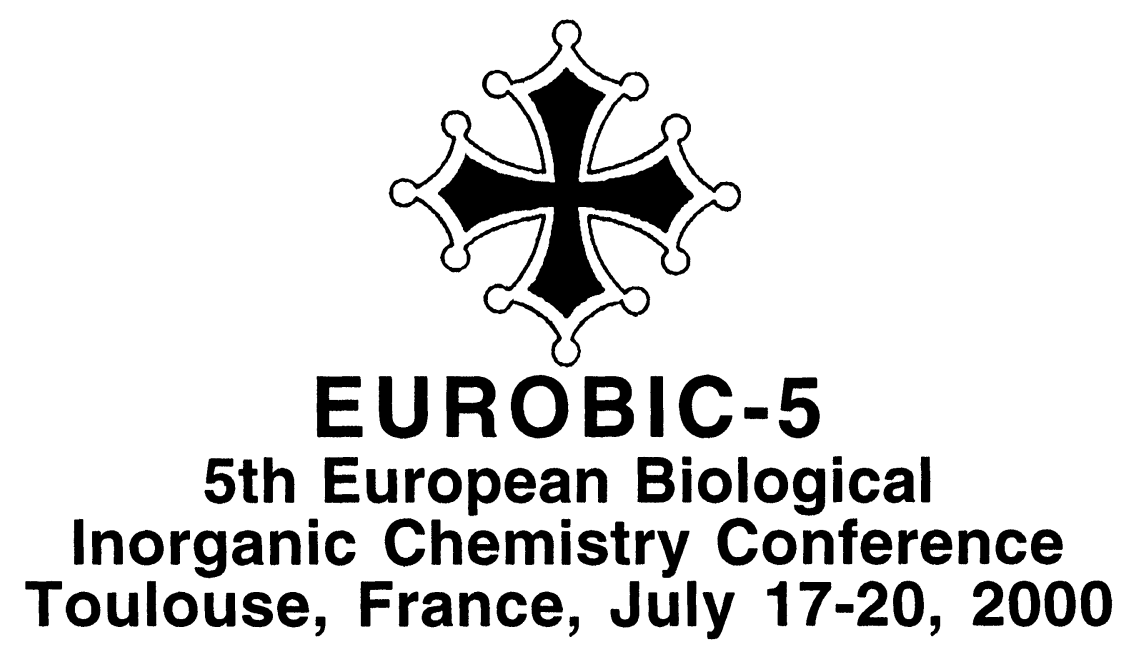

INTERNATIONAL ORGANIZING COMMITEE

S. FORSEN, (Lund, Denmark)

F. GONZALEZ-VILCHEZ (Seville, Spain)

B. MEUNIER (Toulouse, France)

M. A. DE LA ROSA (Seville, Spain)

R. N. F. THORNELEY (Norwich, United Kingdom)

J. ULSTRUP (Lyngby, Denmark)

R. WEISS (Strasbourg, France)

NATIONAL ORGANIZING COMMITTEE

B. MEUNIER, Chairman (Toulouse)

R. WEISS, Co-Chairman (Strasbourg)

J. BERNADOU, Treasurer (Toulouse)

D. NEIBECKER, Vice-Treasurer (Toulouse)

G. BALAVOINE (Bruxelles)

P. BERTRAND (Marseille)

J.-J. BONNET (Toulouse)

M. BRUSCHI (Marseille)

J.-C. CHOTTARD (Paris)

M. COMTAT (Toulouse)

M. FONTECAVE (Grenoble)

J.-J. GIRERD (Orsay)

R. GUILARD (Dijon)

J.-P. LAUNAY (Toulouse)

D. MANSUY (Paris)

I. MORGENSTERN (Orsay)

J.-P. SAUVAGE (Strasbourg)

G. SIMONNEAUX (Rennes)

J.-B. VERLHAC (BordeauX)

LOCAL ORGANIZING COMITTEE
A. BACEIREDO
J. BERNADOU
A.-M. CAMINADE
R. CHAUVIN
J.-P. COSTES
C. HEMMERT
G. LAVIGNE
N. LUGAN
E. MANOURY
B. MEUNIER
G. PRATVIEL
A. ROBERT 
SCIENTIFIC PROGRAMME

EUROBIC-5 will include the following themes:

Biocatalysis with metalloenzymes and related models

Electron transfers in biological systems

Metalloproteins

Metals in medicine

Metals in the environment

Nucleic acids and metal complexes

Physical methods in bioinorganic chemistry

The symposium will hold 10 plenary lectures, 26 section lectures in 2 parallel sessions, 8 oral presentations of selected posters, and 2 poster sessions.

\section{PLENARY LECTURERS}

The following prominent scientists have already agreed to present plenary lectures

I. BERTINI (Florence, Italy): Topic: Progress in NMR of metalloproteins.

J. T. GROVES (Princeton, USA): Topic: Peroxynitrite and metal complexes

B. KREBS (Münster, Germany): Topic: Phosphatase.

J.-M. LEHN (Strasbourg, France):Topic: Supramolecular chemistry.

D. MANSUY (Paris, France): Topic: NO synthase.

J. J. G. MOURA (Monte Caparica, Portugal): Topic: ATP sulfurylase (Co-Zn protein).

P. NORDLUND (Stockholm, Sweden): Topic: X-ray of RNR.

J. REEDIJK (Leiden, The Netherlands): Topic: Platinum chemistry and DNA.

D. S. SIGMAN (Los Angeles, USA): Topic: DNA cleavage.

R. N. F. THORNELEY (Norwich, United Kingdom):Topic: Nitrogen cycle.

\section{GENERAL INFORMATIONS}

The region "Midi-Pyrénées", located in Southwest France, offers a sumptuous historical heritage of ancient monuments, castles, romanesque churches, villages (Cordes) and towns (Albi, Cahors, Carcassonne). Its capital, the ancient city of Toulouse has become home to high technologies linked to aircraft and space industries, electronics, and pharmaceuticals. The quality life-style, famous gastronomy justifying the French paradox (foie-gras, magret, cassoulet, plus local wines), and singing "southern" accent make Toulouse and its region pleasant places to live and to visit. Toulouse can be reached by air (Toulouse-Blagnac International Airport) or TGV from the main European cities. Accommodation will be available in comfortable hotels located downtown, within walking distance of both the conference site and the historical city centre.

The symposium will be held in the "Centre de Congrès Pierre Baudis" located downtown Toulouse

\section{SOCIAL PROGRAMME}

An attractive social programme, including welcoming reception, banquet and concert will be proposed to all participants. A special programme will be available for accompanying persons.

\section{CORRESPONDENCE ADDRESS}

$$
\text { EUROBIC-5 }
$$

Laboratoire de Chimie de Coordination du CNRS

205, route de Narbonne

F-31077 Toulouse Cedex 04, France

Phone: +33561333100

Fax: + 33561553003

E-mail: eurobic5@Icc-toulouse.fr 